FAKTOR-FAKTOR RISIKO PADA

HOST DAN LINGKUNGAN YANG

BERPENGARUH TERHADAP

KEJADIAN SERVISITIS PADA PSK

Diterima 7 Oktober 2016

Disetujui 9 November 2016

Dipublikasikan 1 desember 2016
JKMA

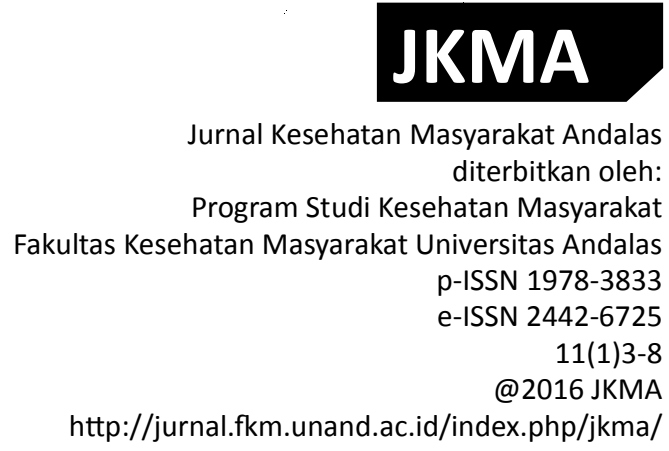

http://jurnal.fkm.unand.ac.id/index.php/jkma/

\footnotetext{
${ }^{1}$ Program Studi Kesehatan Masyarakat Universitas Muhammadiyah Jakarta

${ }^{2}$ Program Studi Doktor Ilmu Kesehatan Masyarakat FKM UNDIP Semarang

${ }^{3}$ Magister Epidemiologi Program Pascasarjana UNDIP Semarang
}

Nazarwin Saputra ${ }^{1 \otimes}$, Bagoes Widjanarko², Henry Setyawan ${ }^{3}$

\begin{abstract}
Abstrak
Infeksi menular seksual (IMS) masih menjadi masalah kesehatan utama dibeberapa bagian dunia. Penelitian ini bertujuan untuk mengetahui faktor faktor host dan lingkungan yang berpengaruh terhadap kejadian servisitis pada pekerja seksual. Jenis penelitian ini adalah observasional dengan rancangan kasus kontrol dengan tehnik consecutive sampling. Faktor risiko yang terbukti berpengaruh terhadap terjadinya servisitis adalah riwayat infeksi menular seksual $(\mathrm{p}=0,0001)$, mempunyai pasangan hubungan seksual (pacar) beda jenis kelamin $(p=0,014, O R=4,4 ; C 195 \%=1,3-14,3)$, riwayat oral seks/cunnilingus $(p=0,003$, $\mathrm{OR}=6,8 ; \mathrm{CI} 95 \%=1,9-24,8)$, perokok $(0,0001, \mathrm{CI} 95 \%=5,6 ; \mathrm{CI} 95 \%=2,4-13,1)$. Perilaku penggunan kondom last sex merupakan faktor protektif yang berpengaruh terhadap kejadian servisitis $(p=0,0001, O R=0,198$; $\mathrm{CI} 95 \%=0,07-0,5)$. Kesimpulan dari penelitian ini adalah untuk mencegah servisitis pada kelompok berisiko pekerja seks komersial maka hendaknya menghindari dari terpajannya agent yang menyebabkan infeksi menular seksual, tidak mempunyai pasangan yang tidak resmi (pacar) yang mengarah ke perilaku seks bebas, menghindari perilaku oral seks/cunnilingus, tidak merokok. Pada perilaku berisiko hendaknya menggunakan kondom untuk pencegahan servisitis
\end{abstract}

Kata Kunci: Faktor, Servisitis, Pekerja Seks Komersial

\title{
RISK FACTORS IN HOST AND ENVIRONMENT FOR CERVICITIS AMONG COMMERCIAL SEX WORKERS
}

\begin{abstract}
sexually transmitted infection (STI) remains a major health problem in some parts of the world. This study aimed to determine the host and environmental factors the effect on the incidence of cervicitis on sex workers. The study was observational case-control design with consecutive sampling technique. Risk factor for cervicitis is a history of sexually transmitted infections $(\mathrm{p}=0,0001)$, have couple (boy friend) different gender $(\mathrm{p}=0,014, \mathrm{OR}=4,4$; CI95\%=1,3-14,3), history of oral sex/cunnilingus ( $\mathrm{p}=0,003, \mathrm{OR}=6,8$; CI95\% $=1,9-24,8)$, smokers ( $\mathrm{p}=0,0001, \mathrm{CI} 95 \%=5,6$; CI95\%=2,4-13,1). Condom use last sex behavior is a protective factor affecting the incidence of cervicitis $(\mathrm{p}=0,0001, \mathrm{OR}=0,198 ; \mathrm{CI} 95 \%=0,07-0,5)$. The conclusion of this study is to prevent servisitis at-risk groups of commercial sex workers it should avoid from exposure of agents that cause sexually transmitted infections, does not have a spouse who is not authorized (girlfriend) that leads to sex behavior, avoid behaviors oral sex / cunnilingus, no smoke. At-risk behavior should use condoms for prevention servisitis
\end{abstract}

Keywords: Factor, Cervicitis, Commercial Sex Worker 


\section{Pendahuluan}

Servisitis merupakan kasus infeksi menular seks yang sering terjadi pada wanita pekerja seksual dimana pada kondisi ini terjadi peradangan serviks yang umumnya akibat dari infeksi organisme seksual, paling sering disebabkan oleh Chlamydia trachomatis atau Neisseria gonorrhoeae. ${ }^{(1)}$

Servisitis meliputi metaplasi skuamosa, inflamasi kronik, poliferasi sel-sel kolumner (perubahan mikro glandular). Metaplasia menimbulkan obliterasi progresif papilla endoserviks dan obstruksi kripta kelenjar sehingga membentuk kista nabothi. Servisitis kronik bersifat jinak dan sering dijumpai. Jika respon epitel terhadap inflamasi sangat berlebihan (atipia reaktif), servisitis kronik ini mungkin dikelirukan dengan neoplasia intrapitel serviks (CIN; Cervic Intraepithelial Neoplasia). ${ }^{(2)}$

Kasus baru infeksi menular seks (IMS) Provinsi Jawa Tengah tahun 2011 ini menjadi 0,7 per 1.000 penduduk perempuan. Jumlah tersebut dari tahun ke tahun semakin meningkat. ${ }^{(3)}$ Jumlah kasus baru IMS di Kota Semarang pada tahun 2010 berdasarkan pelaporan sebanyak 3 per 1.000 penduduk perempuan. (4) Berdasarkan laporan bulanan kasus infeksi menular seks dengan menggunakan pendekatan laboratorium didapatkan gonore, suspek gonore, servisitis mencapai 84,78\% (1650 kasus IMS) untuk kelompok berisiko. ${ }^{(5)}$

Servisitis merupakan faktor risiko terinfeksinya Human Papiloma Virus maka bila servisitis tidak ditangani secara serius maka risiko untuk terinfeksi HPV akan lebih besar. (6) Penyebaran IMS sangat dipengaruhi oleh pola perilaku dan gaya hidup seseorang disisi lain, IMS juga merupakan co-factor infeksi HIV, sehingga peningkatan kasus IMS dapat memungkinkan terjadinya peningkatan kasus infeksi HIV dan AIDS. ${ }^{(7,8)}$

PSK terinfeksi servisitis dan berpotensi menularkan pada mitra seks yang selalu berganti ganti serta akhirnya memudahkan transmisi HIV bagi PSK dan mitra seks. Bila aspek kesehatan ini tidak ditangani secara serius akan sangat berbahaya dan penularan servisitis akan sangat cepat mulai dari PSK, mitra seks dan ke masyarakat umum. Maka berangkat dari rumusan tersebut peneliti ini meneliti lebih lanjut faktor-faktor risiko host dan lingkungan yang berpengaruh terhadap kejadian servisitis pada pekerja seks komersial (studi kasus pada PSK di Resosialisasi Argorejo Semarang).

\section{Metode}

Rancangan penelitian ini adalah suatu studi epidemiologi analitik dimana bertujuan untuk mengetahui besar pengaruh variabel independen terhadap kejadian servisitis. Metode kuantitatif yang digunakan adalah observasional dengan pendekatan case control study. Pada peneltian ini akan dilakukan perbandingan antara kelompok case dan control dengan perbandingan kasus dan kontrol 1:1. Kelompok kasus adalah PSK dengan terdiagnosa servisitis sedangkan kelompok kontrol adalah PSK yang non servisitis. ${ }^{(9)}$

Kelompok kasus dan kontrol akan ditelurusi secara retrospektif terhadap paparan yang mempengaruhi terjadinya kasus servisitis pada PSK. Nilai besar risiko yang lebih akurat antara case dan control penderita servisitis terhadap non servisitis akan diperoleh dengan membandingkan kelompok kasus dengan kontrol tersebut. ${ }^{(9)}$

Lokasi penelitian ini akan dilaksanakan di Resosialisasi Argorejo Kota Semarang. Dilokasi ini terdapat klinik ims dan program penanggulangan HIV AIDS pada kelompok berisiko yang dibina oleh PKBI Gria Asa dan Puskesmas Lebdosari. Waktu penelitian dilaksanakan pada bulan April hingga Juli 2013 dengan subyek penelitian pekerja seks komersial yang memenuhi kriteria inklusi dan eksklusi. Populasi referen adalah seluruh PSK di Kota Semarang. Populasi studi adalah seluruh PSK di Resosia_lisasi Argorejo Kota Semarang, $(n=651)$ yang terpilih untuk masuk ke dalam kelompok kasus dan kontrol. Jumlah sampel pada penelitian ini sebanyak 160 responden terdiri dari 80 kasus dan 80 kontrol. Teknik pengambilan sampel dengan cara consecutive sampling. Kelompok kasus dan kontrol ditetapkan secara legalartis berdasarkan hasil diagnosis paramedik pendekatan sindrom dan laboratorium yang ditemukan di resosialisasi Argorejo pada bulan April hingga 
Juli 2013. Data dianalisasis secara univariat, bivariat dengan chi square dan multivariat dengan regresi logistik berganda.

\section{Hasil}

Resosialisasi Argorejo terletak di lingkungan Rukun Warga IV Kelurahan Kalibanteng Kulon Kecamatan Semarang Barat Kota Semarang. Rehabilitasi sosial Sunan Kuning dikelola oleh pengurus Resos terdiri atas pengasuh laki-laki/papi dan pengasuh perempuan/ mami. Kepengurusan rehabilitasi sosial bertempat di satu kantor di dalam gedung rehabilitasi sosial. Lokalisasi Sunan Kuning mempunyai peraturan yang ditegakkan untuk anak asuh maupun mucikari.

Dari tabel 1 didapatkan informasi varibel yang dimasukan ke dalam multivariat uji regresi logistik ganda adalah umur, riwayat IMS, pasangan HUS beda jenis kelamin, riwayat oral seks, kebiasaan vaginal douching, perilaku penggunaan kondom last sex, perokok, lingkungan pengguna narkoba, pengguna narkoba, pengkonsumsi alkohol dan lama menjadi PSK. Variabel dtersebut diatas dimasukkan ke uji regresi logistik ganda dengan alasan mempunyai $\mathrm{p}<0,25$ atau pun secara substansi penting untuk dimasukan.

Setelah dilakukan uji regresi logistik gan$\mathrm{da}$, maka diperoleh hasil bahwa variabel yang dinilai sangat berpengaruh terhadap terjadinya servisitis. Variabel tersebut dapat dilihat pada tabel 2. Pada tabel 2 variabel yang berpengaruh terhadap kejadian servisitis diantaranya riwayat infeksi menular seksual ( $\mathrm{p}=0,0001)$, mempunyai pasangan hubungan seksual non komersial beda jenis kelamin $(\mathrm{p}=0,014, \mathrm{OR}=4,4$; $\mathrm{CI} 95 \%=1,3-14,3)$, variabel riwayat oral seks/ cunnilingus ( $\mathrm{p}=0,003, \mathrm{OR}=6,8$; CI95\% $=1,9$ 24,8), seorang perokok $(0,0001, \mathrm{CI} 95 \%=5,6$; $\mathrm{CI} 95 \%=2,4-13,1)$. Perilaku penggunaan kondom last sex merupakan faktor protektif yang berpengaruh terhadap kejadian servisitis $(p=0,0001, O R=0,198 ; C I 95 \%=0,07-0,5)$.

Tingkat risiko PSK untuk terinfeksi servisitis apabila PSK tersebut mempunyai riwayat infeksi menular seksual adalah 99,69\%. Tingkat risiko PSK untuk terinfeksi servisitis apabila PSK tersebut mempunyai pasaangan hubungan seksual (pacar) beda jenis kelamin, riwayat oral seks, perokok serta mempunyai faktor protektif perilaku penggunaan kondom last sex adalah 96,16\%.

Variabel yang tidak berpengaruh terhadap kejadian servisitis pada pekerja seks komersial diantaranya umur, lingkungan pengguna narkoba, pengkonsumsi alkohol, lama menjadi PSK, tingkat pendidikan, jenis kontrasepsi, intensitas melakukan hubungan seksual, jumlah mitra seks, perilaku vulva higiene, intensitas mengganti celana dalam, menggunakan jeans ketat, kebiasaan vaginal douching, Kondom last week, pengguna narkoba, pendapatan. $\mathrm{Hal}$ ini mungkin disebabkan ada cara lain yang lebih kuat dalam penyebaran kasus servisitis. Beberapa variabel tidak terpapar dengan agent servisitis secara langsung yaitu Infeksi Chlamydia trachomatis atau Neisseria gonorrhoeae.

\section{Pembahasan}

Adanya hubungan yang siginifikan antara riwayat IMS dengan servisitis dan riwayat IMS merupakan faktor risiko terjadinya servisitis karena responden mempunyai riwayat kontak lansung terpapar dengan agent servisitis yaitu Infeksi Chlamydia trachomatis atau Neisseria gonorrhoeae. Sehingga besar risiko terjadinya servisitis. Servisitis meliputi metaplasi skuamosa, inflamasi kronik, poliferasi selsel kolumner (perubahan mikro glandular). Metaplasia menimbulkan obliterasi progresif papilla endoserviks dan obstruksi kripta kelenjar sehinnga membentuk kista nabothi. ${ }^{(2)}$ Faktor biologi yang dapat meningkatkan risiko tertular infeksi pada wanita adalah adanya paparan kolumnar epitel; pada leher rahim (ektopoik), yang merupukan temuan umum pada remaja. Infeksi Clamidia dan N. gonorrhoea yang merupakan agent dari kejadian servisitis menginfeksi jenis epitel, ketika terkena bersembunyi di endoserviks. Faktor biologis lainnya termasuk kurangnya antibody pelindung yang dihasilkan dari infeksi sebelumnya; penurunan tingkat IgG selama fase folikuler dari siklus mestruasi dibandingkan dengan orang dewasa, pada usia remaja hanya terdapat sedikit hidrogen peroksida pelindung penghasil lactobacilli. ${ }^{(10)}$ 
Tabel 1. Rangkuman hasil analisis univariat variabel bebas terhadap kejadian servisitis

\begin{tabular}{|c|c|c|}
\hline Variabel & $\begin{array}{c}\text { OR } \\
(\mathrm{CI} 95 \%)\end{array}$ & Nilai P \\
\hline Umur & $4,3(2,2-8,4)$ & 0,001 \\
\hline Pendidikan & - & - \\
\hline Jenis kontrasepsi & $0,7(0,4-1,5)$ & 0,6 \\
\hline Intensitas melakukan HUS & $1,0(0,5-1,9)$ & 1,0 \\
\hline Riwayat IMS & - & 0,001 \\
\hline Jumlah mitra seks & $0,8(0,4-1,5)$ & 0,6 \\
\hline Riwayat biseks & - & - \\
\hline $\begin{array}{l}\text { Mempunyai pasangan HUS } \\
\text { beda jenis kelamin }\end{array}$ & $10(3,6-27,4)$ & 0,001 \\
\hline $\begin{array}{l}\text { Riwayat oral seks (cunnilin- } \\
\text { gus) }\end{array}$ & $\begin{array}{c}14,7(4,9 \\
44,3)\end{array}$ & 0,001 \\
\hline Vulva higiene & $0,3(0,03-3,1)$ & 0,6 \\
\hline $\begin{array}{l}\text { Intensitas mengganti celana } \\
\text { dalam }\end{array}$ & $0,7(0,4-1,5)$ & 0,6 \\
\hline Menggunakan celana ketat & $0,8(0,4-1,7)$ & 0,8 \\
\hline Vaginal douching & $1,6(0,7-3,5)$ & 0,25 \\
\hline Kondomm last sex & $\begin{array}{c}0,118(0,05 \\
2,5)\end{array}$ & 0,001 \\
\hline Kondom last week & $1,0(0,5-1,8)$ & 1 \\
\hline Lingkungan perokok & - & - \\
\hline Perokok & $5,3(2,6-10,6)$ & 0,001 \\
\hline $\begin{array}{l}\text { Lingkungan konsumsi } \\
\text { narkoba }\end{array}$ & $\begin{array}{c}2,06(1,03 \\
4,13)\end{array}$ & 0,03 \\
\hline Pengguna narkoba & $4,1(0,4-38)$ & 0,36 \\
\hline $\begin{array}{l}\text { Lingkungan konsumsi } \\
\text { alkohol }\end{array}$ & - & - \\
\hline Pengkonsumsi alkohol & $3,9(2,03-7,6)$ & 0,001 \\
\hline Pendapatan & $1,1(0,5-2,0)$ & 0,8 \\
\hline Lama menjadi PSK & $3,1(1,5-6,2)$ & 0,002 \\
\hline
\end{tabular}

Sebagian besar responden positif servisitis tidak mengetahui bahwa diri terkena servisitis, dokter hanya mengatakan hanya ada radang saja. Persepsi radang tersebut bukan IMS bagi PSK. Penelitian sebelumnya mnyatakan penderita infeksi servisitis berasosiasi kuat dengan terjadinya kandiloma akuminata yang menetap. Penelitian lain melaporkan bahwa riwayat servisitis sebelumnya berisiko menularkan kandiloma akuminata yang merupakan salah satu infeksi menular seksual. ${ }^{(11-13)}$

Pasangan hubungan seksual beda jenis kelamin berpengaruh terhadap kejadian servi- sitis. PSK mempunyai tingkat mobilisasi yang cukup tinggi begitu pula dengan pasangan seksual non komersial (pacar) yang sering berganti-ganti. Sering berganti gantinya pasangan sekual non komersia ini berdampak pada penggunnaan kondom sebagai faktor protektif sering kali tidak diindahkan oleh PSK terbukti dari hasil uji univariat menyatakan alasan tidak menggunakan kondom yang paling banyak adalah karena melakukan hubungan seksual dengan pacar sendiri baik pada kelompok kasus sebesar 27 reponden $(58,7 \%)$ maupun kontrol sebanyak 4 responden $(36,4 \%)$. Penelitian sebelumnya menyatakan seseorang wanita yang mempunyai pasangan HUS baru berbeda jenis atau pria memiliki faktor risiko terinfeksi servisitis hampir 3 kali dibandingkan dengan wanita yang tidak mempunyai HUS baru.

Oral seks / cunnilingus berpengaruh terhadap kejadian servisitis. Oral seks/ cunnilingus dapat menyebabkan iritasi dan merubah keseimbangan kimia dan flora vagina, yang akhirnya dapat terjadi perlukaan serta memudahkan terjadinya infeksi, disamping itu iritas kronik dapat menyebabkan transformasi sel epitel normal menjadi epitel displastik sehingga memudahkan infeksi Clamidia dan N. gonorrhoea yang merupakan agent dari servisitis. ${ }^{(14)}$ Inflamasi atau peradangan maupun ulserasi kulit atau mukosa adalah portal masuk HIV. ${ }^{(10)}$ Pada penelitian sebelumnya menyatakan seorang wanita yang mempunyai riwayat melakukan oral seks akan berisiko terjadinya servisitis dibandingkan yang tidak melakukan oral seks $\left(\mathrm{OR}=2,3\right.$ [95\% CI, 1,2-4,2). . $^{(14)}$

Perokok berpengaruh terhadap kejadian servisitis. Paparan rokok yang konsisten berperan dalam menurunkan respon imun seluler pada mukosa serviks itu sendiri. Nikotin terakumulasi pada mukosa serviks yang dapat menggangu fungsi imunologiknya. Struktur dan fungsi epitel serviks yang belum sempurna paparan rokok dapat menurunkan respon imun seluler. ${ }^{15)}$ Merokok pada penelitian sebelumnya dinyatakan berhubungan dengan inflamasi dan infeksi seviks. ${ }^{(16)}$

Kondom lateks yaitu jenis kondom ekstra tipis dan aneka rasa dirancang mempunyai permeabilitas membran yang dapat meng- 
Tabel 2. Model akhir uji regresi logistik ganda variabel bebas terhadap kejadian servisitis

\begin{tabular}{lllllllll}
\hline Variabel & \multirow{2}{*}{$\mathrm{B}$} & $\mathrm{SE}$ & Uji Wald & $\begin{array}{l}\text { Nilai } \\
\mathrm{p}\end{array}$ & $\begin{array}{l}\text { Exp } \\
\text { (B) }\end{array}$ & \multicolumn{2}{c}{ 95\% CI exp (B) } \\
\cline { 8 - 10 } & & & & & Bawah & Atas \\
\hline Pasangan HUS beda jenis kelamin & 1,482 & 0,601 & 6,078 & 0,014 & 4,402 & 1,355 & 14,303 \\
Riwayat oral seks/Cunilingus & 1,928 & 0,654 & 8,680 & 0,003 & 6,877 & 1,907 & 24,801 \\
Perilaku penggunaan kondom last sex & $-1,617$ & 0,472 & 11,715 & 0,001 & 0,198 & 0,079 & 0,501 \\
Perokok & 1,723 & 0,433 & 15,873 & 0,000 & 5,603 & 2,400 & 13,079 \\
Constanta & $-0,295$ & 0,452 & 0,424 & 0,515 & 0,745 & & \\
\hline
\end{tabular}

hambat lewatnya orgasnisme dalam berbagai ukuran seperti spermatozoa dengan diameter $0,003 \mathrm{~mm}(3000 \mathrm{~nm})$ dan juga patogen penyebab penyakit seksual N. gonorrhoeae $(800$ $\mathrm{nm})$, C. trachomatis (200 nm), HIV (125 nm) dan Hepatitis B (40 nm).Pada jenis kondom ekstra safe mempunyai lubrikasi yang berfungsi untuk memudahkan ketika memasang dan lebih nyaman ketika digunakan. Beberapa lubrikasi pada kondom mempunyai tambahan yang mengandung spermacide dan banyak digunakan adalah Nonoxynol 9. Nonoxynol 9 dapat membunuh sperma, bakteri dan beberapa virus, sehingga dapat menambahkan level perlindu ngan jika semen keluar dari kondom dan dapat mengurangi kemungkinan terjadi kehamilan. ${ }^{(17)}$

Hasil penelitian sebelumnya menunjukkan ada faktor risiko penggunaan kondom yang tidak konsisten, jenis kondom ekstra tipis, cara penggunaan kondom yang tidak sesuai (sebelum ereksi), kurangnya menjaga kebersihan organ genital dengan baik dan penggunaan antiseptik yang tidak teratur setelah melakukan hubungan seks. ${ }^{(17)}$

Kesimpulan Faktor faktor yang terbukti berpengaruh terhadap kejadian servisitis riwayat infeksi menular seksual, mempunyai pa sangan hubungan seksual (pacar) beda jenis kelamin, riwayat oral seks/cunnilingus, perokok merupakan. Perilaku penggunan kondom last sex merupakan faktor protektif yang berpengaruh terhadap kejadian servisitis. Tingkat risiko PSK untuk terinfeksi servisitis apabila PSK tersebut mempunyai riwayat infeksi menular seksual adalah 99,69\%. Tingkat risiko PSK untuk terinfeksi servisitis apabila PSK tersebut mempunyai pasangan hubungan seksual (pacar) beda jenis kelamin, riwayat oral seks/cunnilingus, perokok serta mempunyai faktor protektif perilaku penggunaan kondom last sex adalah $96,16 \%$.

\section{Ucapan Terima Kasih}

Peneliti mengucapkan terima kasih sebesar besarnya kepada seluruh pihak yang telah membantu terlaksananya penelitian ini diantaranya kepada Kepala Dinas Kesehatan Kota Semarang, Kepala puskesmas Lebdosari Kota Semarang, pengurus resosialisasi argorejo, ketua LSM Gria Asa, Ketua PKBI Kota Semarang.

\section{Daftar Pustaka}

1. Marrazzo JM, Handsfield HH, Whittington WL. Predicting chlamydial and gonococcal cervical infection: implications for management of cervicitis. Obstet Gynecol 2002; 100:p 579-84.

2. Richard N. Mitchell, et al. BS Dasar patologis penyakit edisi 7. Jakarta: Penerbit buku kedokteran EGC. 2009. Hal. 614-615

3. Subdin P3 Dinkesprop Jateng. Laporan Kasus IMS di Propinsi Jawa Tengah Tahun 2011. Semarang: Dinkesprop Jateng. 2012

4. Subdin P2M DKK Semarang. Laporan Kasus IMS di Kota Semarang Tahun 2010. Semarang : DKK Semarang. 2011.

5. Subdin P2M DKK Semarang. Laporan Kasus IMS di Kota Semarang Tahun 2011. Semarang : DKK Semarang. 2012.

6. Gupta S, Sodhani P, Sharma A, Sharma JK, Halder K, Charchra KL, et al. Prevalence of high-risk human papillomavirus type 16/18 infection among women with normal cytology: risk factor analysis and implications for screening and prophylaxis. Journal Compilation Noida. India Cytopathology 2009. 20, p 249-255 a

7. Daili FS. Tinjauan Penyakit Menular Sek- 
sual dalam Ilmu Penyakit Kulit dan Kelamin. Edisi 3. Jakarta: FK UI. 2000. Hal. $1-3$

8. Edy W. Praktik Wanita Pekerja Seks (WPS) Dalam Pencegahan Penyakit Infeksi Menular Seksual (IMS) Dan HIV\&AIDS Di Lokalisasi Koplak, Kabupaten Grobogan. Jurnal Promosi Kesehatan Indonesia. Agustus 2009; vol 4; no 2; Hal. 94-102

9. Silman AJ. Epidemiological studies : a practical guide, Cambridge University Press, Cambridge, 1995, 44-56

10. Risser WL, Bortot AT, Benjamins LJ, et al. The Epidemiology of sexually transmitted infection in adolescent. Seminar pedeatr Infect Dis 16: 160-167. 2005 Elsevier Inc

11. Moscicki A, Hills N, Shiboski S. Risk for Incident Human Papillomavirus Infection and Low Grade Squamous Intraepithelial Lesion Development in Young Females. J Am Med Assc. 2001; vol 285; no 23.

12. Amo J, Gonzalez, Losana, et al. Sex Workers : Influence of age and geographical origin in the prevalence of high risk human papillomavirus in migrant female sex workers in Spain. Sex Transm Infect. 2005; vol 81; p $79-84$.

13. Samoff, Koumans, Markowitzs et al. Association of Chlamydia trachomatis with Persistence High Risk Types of Human Papillomavirus in a Cohort of Female Adolescents. Am J of Epidemiology. 2005. vol 162, no 7, p $668-675$

14. Marrazzo JM, Wiesenfeld HC, Murray PJ, Busse B, Meyn L, Krohn M, Hillier SL. Risk Factors for Cervicitis among Women with Bacterial Vaginosis. The Journal of Infectious Diseases 2006; 193: p 617-24

15. Marrazzo JM, Martin DH. Management of women with cervicitis. Clin Infect Dis 2007;44 (Suppl 3):S102-10

16. Critchlow CW,Wolner-Hanssen P, Eschenbach DA, et al. Determinants of cervical ectopia and of cervicitis: age, oral contraception, specific cervical infection, smoking, and douching. Am J Obstet Gynecol 1995; 173:534-43

17. Arifin NF, Ginandjar P, Udiyono A. Penggunaan kondom dan vaginal higiene se- bagai faktor risiko kejadian infeksi menular seksual pada wanita pekerja seks di Lokasi Batu 24 Kabupaten Bintan. Jurnal Kesehatan Masyarakat. Vol. 1. No. 2. Tahun 2012. Hal. 357 - 363 